\title{
THE ANALYSIS OF DIFFICULTIES IN WRITING NARRATIVE TEXT
}

\author{
Septha Muliani \\ museptha@gmail.com \\ Maida Norahmi \\ maida.norahmi12@edu.upr.ac.id \\ Natalina Asi \\ natalina@edu.upr.ac.id
}

University of Palangka Raya, Indonesia

\begin{tabular}{|c|c|}
\hline Received: $18^{\text {th }}$ November 2019 & $\begin{array}{l}\text { The objective of this research was to analyze the } \\
\text { difficulties in writing narrative text faced by the }\end{array}$ \\
\hline Accepted: $14^{\text {th }}$ December 2019 & Raya in the academic year $2018 / 2019$ in using the \\
\hline Corresponding Author: & $\begin{array}{l}\text { generic structure and language features of the text. } \\
\text { The research involved } 20 \text { students as the research }\end{array}$ \\
\hline Tel.: & $\begin{array}{l}\text { participants. The method used in this research was } \\
\text { descriptive research in which the research }\end{array}$ \\
\hline maida.norahmi12@edu.upr.ac.id & $\begin{array}{l}\text { described and explained the actual data by } \\
\text { conducting a writing test and analysing the results. }\end{array}$ \\
\hline Keywords: & $\begin{array}{l}\text { The results showed that } 40 \% \text { of the participants } \\
\text { faced some difficulties in constructing the generic }\end{array}$ \\
\hline Analysis; Generic & structure of the texts i.e. they failed in completing \\
\hline Structure; Language & $\begin{array}{l}\text { the generic structures of the texts and, mostly, } \\
\text { missed one of the parts. Furthermore, there were }\end{array}$ \\
\hline Feature; Narrative Text; & $50 \%$ of the participants faced some difficulties in \\
\hline Writing Difficulties & $\begin{array}{l}\text { using the language features of narrative text, such } \\
\text { as using past tenses, nouns, pronouns, verbal } \\
\text { processes, and direct speech. }\end{array}$ \\
\hline
\end{tabular}




\section{INTRODUCTION}

Language has an essential role in human communication and interaction. The ability to use language as a tool to express ideas and emotions is a fundamental need regarding its function in human social life. In other words, the language is used to show feelings, desires, opinions, and attentions to create social engagement throughout the differences of identities and personal background. The language becomes one of the main determining factors to connect all people around the world and to make some collaborations (Lieberman \& Miller, 2011). To reach wider network of communication, there should be one universal language to build the bridge of international collaboration and interaction. That is why an international language is needed as a tool to unite people and to have more people involved in sharing experiences (Klimova, 2014). Following the raising need for international communication, English becomes so popular to be taught and learned by those want to participate in wider interaction.

In maintaining a social life and being social media users, people have been treating English as the most used language. To be able to cope with globalization and the development of technology, English is a necessary tool for those who want to get along with global issues (Sharma, 2008; Ur, 2010). According to Simons and Fennig (2018), there are 7.097 living languages used in the world and they are the ultimate sources of information. The record data show that English is mostly used in communication media. Based on the data, it can be concluded that the role of English is getting important to help people be connected to wider society. It means the urgency and the demand for being able to use English should be put under consideration. Therefore, English has to be taught as intensive as possible in order to provide some exposures to make people familiar with the language in their daily interactions.

The need to learn English leads to the idea of teaching English formally and intensively as a school subject, so the students can learn English from schools. Many non-speaking countries have treated English as a compulsory subject to learn. Indonesia is one of many countries that uses English as important subject in the educational field from the elementary schools up to the universities. In primary 
schools, the teaching of English is inserted in a local content subject. It means that the process of English teaching and learning is based on the policies made by the schools. In secondary and tertiary schools, English is included in compulsory subjects and is tested in the national examination. For university students, English is treated as one of the compulsory general courses that every student has to take and pass the course. Differently from the English for junior and senior high schools, English is taught as English for Specific Purposes (ESP) subject in the university (Brajac 2014; Javid, 2015). In other words, the content of learning must be related to the specific departments or programs taken by the students.

In the process of learning English, the students must learn four skills, i.e. listening, speaking, reading and writing. In the new modern world, Morse (2016) proposed idea to have additional skills. He stated that people would be required to have six skills to live in a time when the technology is rapidly changing and shape how they communicate and interact each other. The six new skills are listening, speaking, reading, writing, viewing and representing. Viewing and representing are the newest skills that are needed in this era. Many of the comprehension processes involved in reading, such as previewing, predicting, and making inferences, may also be used in viewing. Representing enables students to communicate information and ideas through a variety of media, such as video presentations, posters, diagrams, charts, symbols, visual art, drama, mime, and models.

Among all of the language skills, writing is the one skill that realized in written form which is necessary for the academic field (Morse, 2016). Writing is a highly complex process that requires the ability to create ideas and to display the ideas in a well-structured piece of writing. Before a writer writes something, he or she should check out some aspects. The writer should formulate ideas, organize, and sequence points in logical order, select vocabulary, check for grammatical correctness, spell words correctly, punctuate, and write clearly. As being stated by Fry (2012), before and after writing process, a writer should check their paper. The purpose of checking is to ensure that the writing has good structures to be read and comprehended by the readers.

According to Oshima and Hogue (1998), writing is not easy, it takes to study and practice to develop this skill for both native speakers and new learners of 
English. Writing is different from other language skills. In listening and reading, the students receive message that is formulated by another. Whereas in speaking, the students communicate using their own ideas and feeling. From the explanation above, it can be concluded that writing is important and also different from other skills. It is a complex skill that needs some of process inside it, such as putting learners' ideas with grammatical, vocabulary, and punctuation into a written form. However, writing is not only an activity of arranging words, sentences, and paragraphs, but also thinking about how to express and organize them with creativity.

According to the English syllabus of school-based 2013 curriculum of ninth grade of SMP Negeri 11, the students are taught to be able to write various genres of text, such as descriptive texts, recount texts, procedure texts, and narrative texts. Writing narrative text is no easy task for tenth-grade students in Palangka Raya because to write a task the students have to know about the generic structures and language features. Normally, narrative text can be categorized into fictional or imaginary narrative and nonfictional narrative. The fictional narrative presents an imaginary story that happened in an imaginary world. Such as fairy tales, folktales, short stories, fables, legends, myths, novels, and comics. Meanwhile, a nonfictional narrative presents a story of person's real-life. The examples of narrative nonfiction include news and magazine articles, essays, diaries, biographies, personal narratives and textbooks that tell about history. From the definition, it can be concluded that narrative is retelling stories that occurred in the past by using chronological order and sequence of events to amuse or entertain the readers.

In line with this, Sudarwati and Grace (2017) stated that narrative text has a social function to entertain the reader with a story that deals with complications or problematic events that lead to a crisis and in turn find a resolution. In other words, it is to amuse, to entertain and to deal with actual or vicarious experience in different ways. In writing the texts, the writer must follow the generic structure of narrative texts since different texts will require different generic structure. The generic structure of narrative text consists of 4 aspects, they are orientation, complication, resolution, and re-orientation. The writer should be able to explain the background of the story including the setting of place and time as well as the introduction of the 
characters (orientation). After setting the background of the story, the writer has to provide the readers with the problems faced by the main character to lead the reader into the climax of the story (complication). Further information to provide is telling the readers whether the problems are solved happily or tragically (resolution). Finally, the story should give the readers any valuable messages that can impact the readers' personalities or perspectives to live in society (re-orientation). The four aspects mentioned cannot be ignored when the students create their own piece of narrative texts.

Another important point in writing narrative texts is how the students should utilize language features or significant grammatical features to support the flow of the story. It deals with the grammatical features such as noun, pronoun, tenses, phrase, and any structure that support the body of the story. There are some specific grammatical aspects that have to be used in narrative texts, such as the nouns (forest, house, train), pronouns (they, she, it), noun phrases (old man, red apple), time Connectives/ Conjunctions (one day, after, before), adverbs/ adverbial phrases (In the place, there), action verbs (walked, smiled), and the past tense (She walked slowly). These features can be very problematic for the students since they have to generate ideas and put the ideas incorrect grammatical structures.

Regarding the researcher's experiences of teaching in SMP Negeri 11 Palangka Raya, she found that some students got difficulties in the process of writing a text, especially narrative text. Some of the students got problems in developing the ideas. The students put so many ideas without organizing them into good sentences and paragraphs. On the other side, some students, sometimes, had no idea what they would write and they only wrote a sentence or even they did not write anything on their paper. Moreover, some of students had difficulties in generic structure and language features. Some of them did not understand how to apply generic structure and language features in writing narrative text. For example was sentence structure, some of them did not know how to use tenses in the right way. In a text that was actually used past tense such as narrative text, they used present tense. Another example, some of them also had limited vocabulary range. They could not build their ideas to write on their papers because they did not have enough vocabulary in English. 
Based on the fact above, the researcher was interested in analyzing students' difficulties in writing narrative text at the ninth grade of SMP Negeri 11 Palangka Raya in the academic year 2018/2019. The ability in writing narrative text is one of the objectives in teaching English that has to be achieved in the ninth grade. Based on the problem explained above, the objective of this research was to analyze the difficulties in writing narrative text faced by the ninth grade students of SMP Negeri 11 Palangka Raya in academic year 2018/2019, especially in constructing the generic structure and using language features of the text.

\section{METHOD}

In this research, the kind of research used was descriptive research. There are three main purposes of research: describing, explaining, and validating the findings. Description emerges following creative exploration, and serves to organize the findings in order to fit them with explanations, and then test or validate those explanations. The descriptive method is a research methodology concentrated on the actual matters when the data are firstly collected in the method, describes and analyzes the actual matters that observed in this research were the students' difficulties in writing narrative text.

In this research, the subjects were 20 students of class IX-C of SMP Negeri 11 Palangka Raya in the academic year 2018/2019. In order to collect the data, the researcher used writing test. The test was designed and used as an instrument to evaluate and record the students' difficulties. The time allocation given to write a narrative text was 60 minutes. The test administration was monitored by the main researcher and the teacher.

The instrument that the researcher developed in this research was a writing test. In the writing test, the students were assigned to write a fiction-based narrative text that was retelling about the fairy tale, legend, or fables such as Malin Kundang or The Story of Mouse Deer (Cerita Si Kancil) in students' own version. The researchers also gave the original story to the students. This test was conducted to find out the difficulties of the students in writing narrative text. In this research, the aspects identified were generic structures and language features.

Septha Muliani

LET: Linguistics, Literature and Language Teaching Journal Vol. 9 No. 22019 
Before the instrument used to collect the data, firstly, the researcher did the try-out for the test to the ninth grade students of SMPN 11 Palangka Raya. There were 19 students from IX-B as the respondents of the try-out test. They had to complete the test, consisting of the writing test in 60 minutes. Based on the try-out result, there was no problem with the test. The try-out test was $100 \%$ was acceptable for the respondents. They followed the instruction to write a narrative text and it meant that the instruction was understandable for them. None of them wrote the wrong text. Then, they also did not have complaints with the allocation time. The researchers concluded that 60 minutes was enough for the students to write a narrative text. In conclusion, the instrument was ready to be used and to be administered to the subjects of the research.

The extent to which a data collection process really measures what it is designed to measure is the concept of the validity of data collection processes. It could be said that the concept of validity refers to what the test or measurement strategy measures and how well it does so. The instrument validity that used in this research were content validity and face validity.

Content validity refers to the extent to which a data collection process measures a representative sample of the subject matter or behavior that should be encompassed by the operational definition. It means that the test will be suitable for content validity if it is also suitable the course objective as stated in syllabus. In this test, content validity was the students were expected to be able to write narrative text. For that reason, the researcher gave the students the writing instruction to make a text-based on fiction type that retelling about fairy tales, fables, or legends by students' own version.

Face validity measures the extent to which a test appears to measure what it is intended to measure. It is concerned about the relevance of a test as it appears to the subjects. In other words, the writing test constructed was able to make the students write as it was told. In this research, the researcher did try-out test before conducting the writing test to the subjects to check the face validity. Face validity in this research was concerned about the writing test instruction and the time allocation to write a narrative text.

Septha Muliani

LET: Linguistics, Literature and Language Teaching Journal Vol. 9 No. 22019 
Following the data collection process proposed by Cresswel (2012), the researchers used five steps to collect the data. At the beginning of the process, the researchers discussed and selected the place of the research and subjects of the research. It was conducted by reviewing the documents and asking the school administrators. Secondly, the researchers visited SMP Negeri 11 Palangka Raya and had an informal interview with the teacher. The result of the interview gave the researchers additional information dealing with the characteristics of the students and the lessons have been taught. Next, after the permission was given and the analysis of interview was discussed, the researchers decided the schedule and prepared the test and the topic, and the writing sheets. Fourthly, the researchers came to the class, met the research subjects, and explained the instructions to accomplish the test. The researcher gave 60 minutes to the students to write narrative texts based on the topic chosen. Finally, The researcher collected the students' writing sheets and prepared them to be analysed based on the decided parameter or rubric for the data analysis process. The rubric constructed included the assessment indicator on generic structure and the language features.

The next step was to analyze the narrative texts written by the students. In processing the data, the researchers, firstly, did a checking process in which the researchers checked the number of students, the number of students' worksheets and the content of students' worksheets. The researchers also ensured that the worksheets were complete as the number of students. Coding was the second process in analyzing the data. The researcher coded the students' names in order to protect the students' privacy and avoid researchers' subjectivity by giving some codes such as $\mathrm{X} 1, \mathrm{X} 2, \mathrm{X} 3$, etc. The next process was to evaluate the narrative texts based on the provided rubric. The researchers read the texts and identified the difficulties in writing narrative text that was made by the students based on the scoring system on writing. The last step was to tabulate the students' scores. The researcher arranged the data into a table after the difficulties were being identified. The data was clearly seen through the table after they were being analyzed.

Septha Muliani

LET: Linguistics, Literature and Language Teaching Journal Vol. 9 No. 22019 


\section{FINDINGS AND DISCUSSIONS}

The test was administered in SMPN 11 Palangka Raya and was given to twenty students of the ninth grade. After obtaining and analyzing the students' scores in writing narrative text, the researcher calculated the percentage. The calculation was based on the scales and their indicators in the scoring rubric. There were four scales to analyze and assess the generic structure. The scale 4 showed the highest quality of the generic structure. It showed that the narrative texts consisted of orientation, complication, resolution, and re-orientation. The scale 3 showed that the narrative texts missed one of the four parts of generic structure. The scale 2 was given to the narrative texts which missed two of the four parts of generic structure. The last, scale 1 represented that the narrative texts only consisted orientation, without complication, resolution, and re-orientation.

In assessing the language features, the researchers implemented a five-point scale. The language features assessment was focused on the use of past tense. Scale 5 represented that the narrative texts had no error in the use of past tense. The scale 4 showed that the narrative texts had 1-4 errors in the use of past tense. If there were 5-8 errors in the use of past tense, scale 3 was given. Responding to 9-11 errors in the use of past tense, the narrative texts were given scale 2 . The least quality was to give the scale 1 to the texts that had more than 12 errors in the use of past tense.

Table 1 The Percentage and Total Score of Students' Difficulties in Each Score in Writing Narrative Text

\begin{tabular}{rcccc}
\hline \multirow{2}{*}{ Aspect } & \multicolumn{5}{c}{ Score } \\
\cline { 2 - 5 } & 4 & 3 & 2 & 1 \\
\hline Generic Structure & 7 & 5 & 6 & 2 \\
& $(35 \%)$ & $(25 \%)$ & $(30 \%)$ & $(10 \%)$ \\
\hline & 5 & \multicolumn{4}{c}{ Score } \\
\hline
\end{tabular}

Septha Muliani

LET: Linguistics, Literature and Language Teaching Journal Vol. 9 No. 22019 


\begin{tabular}{lccccc}
\hline & 1 & 9 & 5 & 3 & 2 \\
Language Features & $(5 \%)$ & $(45 \%)$ & $(25 \%)$ & $(15 \%)$ & $(10 \%)$ \\
\hline
\end{tabular}

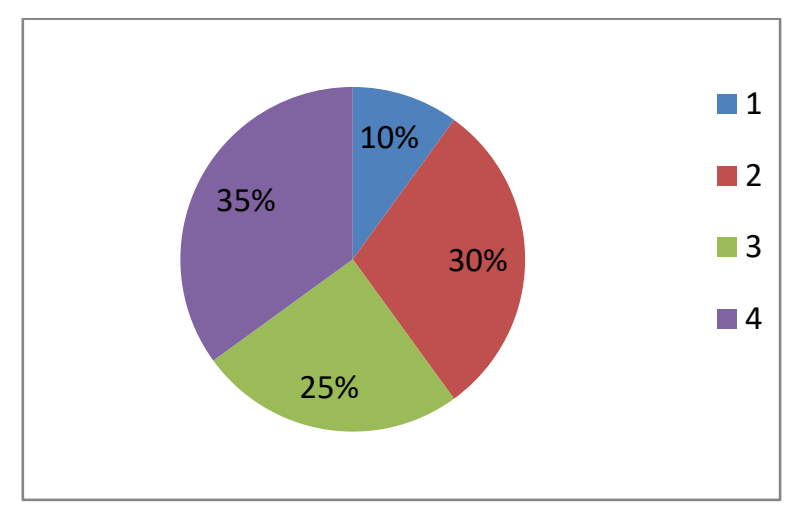

Figure 1 The Percentage of Students' Difficulties in Generic Structure

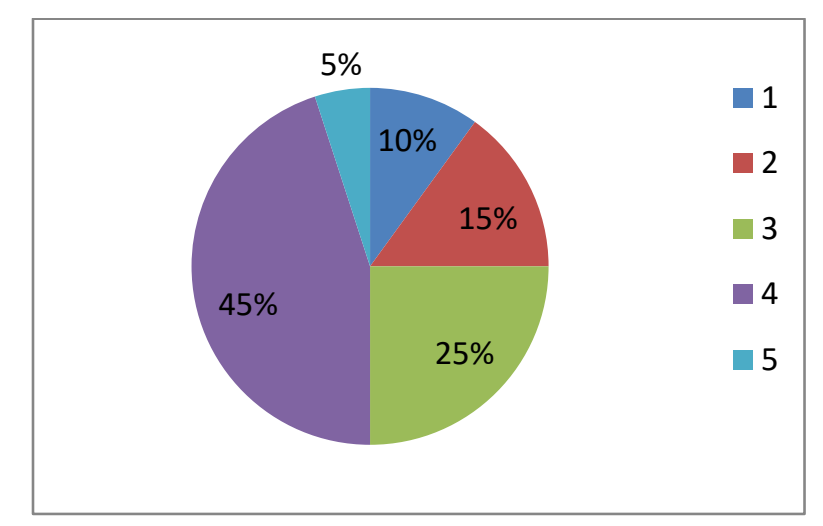

Figure 2. The Percentage of Students' Difficulties in Language Features

The students who got scale 1 and 2 in generic structure and get scale 1, 2, and 3 in language features were categorized as having difficulties. For generic structure, there were $8(40 \%)$ students had difficulties. The students had difficulties in formulating the orientation, complication, and resolution.

There were 6 students (30\%) who got the scale of 2 since they did not write complete major parts in generic structure. The narrative texts contained only 2 parts of the generic structure (orientation and complication or orientation and resolution). Next, there were 2 students $(10 \%)$ who got the scale of 1 did not contain 3 major 
parts of generic structure. To be more specific, there was only orientation part in their narrative texts. For language features, there were $10(50 \%)$ students had difficulties. The students had difficulties in using grammar, especially in using past tense. Firstly, there were 5 students (25\%) who got the scale of 3 since they had 58 grammatical errors in the use of past tense. Secondly, there were 3 students (15\%) who got the scale of 2 since the narrative texts had 9-12 errors in the use of past tense. The last, there were 2 students $(10 \%)$ who got the scale of 1 since there were more than 12 errors in the use of past tense.

\section{Generic Structure}

On the difficulties in generic structure, it could be seen from the previous explanation that in the generic structure was $40 \%$ of students' difficulties in writing narrative text. There were 4 types of students' difficulties in generic structure of writing narrative text. Firstly, some of students only wrote orientation and complication without resolution that contained ending of the story. Secondly, some of students only wrote complications and resolutions without orientation that told the main character of the story. Thirdly, some of students only wrote orientation, they did not write complication and resolution. Fourthly, some of students only wrote resolution without orientation and complication. Susanti (2017) said that orientation was an element of narrative text that told introduction of the story to the reader. Orientation consisted one or more sentences, or usually in one short paragraph that told the reader who the character was, where it happened, and when it happened. The students of type 2 and 4 did not write the orientation in their story, so the story was not complete. The reader would be confused because there was a jump to the complication or the resolution without knowing the characters, the background of time and of place of the story. According to Nuzhatun (2016), complication was a period when a crisis or problem turned out. The complication made story more interesting because the character was prevented to reach what he or she wanted. In other words, it was the middle of the story when the problem faced by the character. Longknife and Sullivan (2012) also said that complications added interest in the story. The reader had to picture, so they were more engaged in the story.

Septha Muliani

LET: Linguistics, Literature and Language Teaching Journal Vol. 9 No. 22019 
Table 2 The Description of Students' Difficulties in the Generic Structure

\begin{tabular}{|c|c|c|}
\hline \multirow[b]{2}{*}{ No. } & \multirow{2}{*}{$\begin{array}{l}\text { Students' } \\
\text { Code }\end{array}$} & Generic Structure \\
\hline & & $\begin{array}{l}\text { Difficulties in Orientation, Complication, } \\
\text { Resolution, Re-Orientation (Optional) }\end{array}$ \\
\hline 1. & $\mathbf{X} 1$ & $\begin{array}{l}\text { X1 did not write } 3 \text { major parts of generic structure that } \\
\text { were orientation, complication or resolution. He/she did } \\
\text { not write who was Cinderella and also did not write } \\
\text { clearly what was the major complication. He/she did } \\
\text { not write the resolution that contained end of the story, } \\
\text { either in happy or sad ending. }\end{array}$ \\
\hline 2. & $\mathrm{X} 2$ & $\begin{array}{l}\text { X2 had difficulties in writing the complication and the } \\
\text { resolution. He/she did not write clearly what was the } \\
\text { major complication. He/she also did not write the } \\
\text { resolution that contained end of the story, either in } \\
\text { happy or sad ending. }\end{array}$ \\
\hline 3. & $\mathbf{X 3}$ & $\begin{array}{l}\text { X3 had difficulties in writing the complication and the } \\
\text { resolution. He/she did not write clearly what was the } \\
\text { major complication. He/she also did not write the } \\
\text { resolution that contained end of the story, either in } \\
\text { happy or sad ending. }\end{array}$ \\
\hline 4. & X5 & $\begin{array}{l}\text { X5 did not write } 3 \text { major parts of generic structure that } \\
\text { were orientation, complication or resolution. He/she did } \\
\text { not write who was the main character in the orientation } \\
\text { and also did not write clearly what was the major } \\
\text { complication. He/she did not write the resolution } \\
\text { clearly. }\end{array}$ \\
\hline 5. & X6 & $\begin{array}{l}\text { X6 had difficulties in writing the orientation and the } \\
\text { complication. He/she did not write who was Cideralla } \\
\text { and also did not write what was the major complication. }\end{array}$ \\
\hline
\end{tabular}




\begin{tabular}{ll}
\hline He/she just wrote the resolution that contained a happy \\
ending for the main character. \\
X7 had difficulties in writing the complication and the \\
resolution. He/she did not write clearly what was the \\
major complication. He/she also did not write the \\
resolution that contained end of the story, either in \\
happy or sad ending. \\
X11 had difficulties in writing the complication and the \\
resolution. He/she did not write clearly what was the \\
major complication. He/she also did not write the \\
resolution that contained end of the story, either in \\
happy or sad ending. \\
X19 had difficulties in writing the complication and the \\
resolution. He/she did not write clearly what was the \\
major complication and did not write the resolution \\
write the resolution clearly. \\
\hline
\end{tabular}

The students of type 3 and 4 did not write the complication. Some of them only wrote the orientation and some of them only wrote the resolution without the complication. Based on Susanti (2017), resolution was an element of the narrative text where the character found out the solution about the problem in the complication. Longknife and Sullivan (2012) also stated that the resolution was the last part when the main character cleaned up the problem. In other words, resolution told the end of the story, either in a happy ending or in a sad ending. The students type 1 and 3 did not write the resolution. Some of students only wrote the orientation and the complication and some of them only wrote the orientation. The story was not complete and clear without the resolution that had a function to tell the end of the complication. Based on explanation above, the students had difficulties wrote with generic structure. The difficulties were on how the students could write orientation, complication, and resolution. Another difficulty that the researcher found was generating idea. Many students were lack of vocabulary when they wrote 
narrative text. Some of them only wrote less than a paragraph and also they thought the time was very short to write.

\section{Language Features}

On the difficulties of language features on grammar, it could be seen from the previous explanation that there were $50 \%$ of students faced problems in language features of writing the narrative texts. It seemed that most of students had difficulties in using past tenses, nouns, pronouns, verbal processes, and direct speech. Byrne in Fareed, et. al. (2016) stated that writing difficulties were linked to three categories. They were psychological, linguistic, and cognitive problems. In this research, the data showed that the difficulty in linguistic factors was the main problem for the students.

Table 3 The Description of Students' Difficulties in the Language Features

\begin{tabular}{|c|c|c|c|}
\hline \multirow{3}{*}{ No } & \multirow{3}{*}{$\begin{array}{l}\text { Students' } \\
\text { Code }\end{array}$} & \multicolumn{2}{|c|}{ Language Features } \\
\hline & & \multicolumn{2}{|c|}{ Difficulties in Grammar and The Use of Past Tense } \\
\hline & & $\begin{array}{l}\text { Students' Words/ } \\
\text { Sentences }\end{array}$ & Corrected Words/ Sentences \\
\hline \multirow{3}{*}{1.} & \multirow{3}{*}{$\mathbf{X 3}$} & $\begin{array}{l}\text { X3 had difficulties } \\
\text { writing with past tense } \\
\text { and direct speech. X3 } \\
\text { wrote : } \\
\text { a mouse deer walking } \\
\text { in the forest }\end{array}$ & $\begin{array}{l}\text { It should be : } \\
\text { a mouse deer was walking in } \\
\text { the forest }\end{array}$ \\
\hline & & $\begin{array}{l}\text { Then, he/she did not use } \\
\text { quotation marks (“" “) for } \\
\text { direct speech : } \\
\text { Oh all right said mouse } \\
\text { deer }\end{array}$ & $\begin{array}{l}\text { It should be : } \\
\text { "Oh all right" said the mouse } \\
\text { deer }\end{array}$ \\
\hline & & $\mathrm{He} /$ she also wrote & $\begin{array}{l}\text { They should be the mouse } \\
\text { deer and the tiger. }\end{array}$ \\
\hline
\end{tabular}




\begin{tabular}{|c|c|c|c|}
\hline & & $\begin{array}{l}\text { mouse deer and tiger as } \\
\text { nouns without determiner } \\
\text { "the". }\end{array}$ & \\
\hline \multirow{3}{*}{2.} & \multirow{3}{*}{ X4 } & $\begin{array}{l}\text { X4 had difficulties in } \\
\text { writing past tense. } \\
\text { He/she wrote : } \\
\text { Cinderella forget her } \\
\text { mother }\end{array}$ & $\begin{array}{l}\text { It should be : } \\
\text { Cinderalla forgot her mother }\end{array}$ \\
\hline & & $\begin{array}{l}\text { Then, he/she wrote : } \\
\text { Malin Kundang waiting }\end{array}$ & $\begin{array}{l}\text { It should be : } \\
\text { Malin Kundang was waiting }\end{array}$ \\
\hline & & $\begin{array}{l}\text { He/she also did not write } \\
\text { the pronoun and the right } \\
\text { adverbial phrase in a } \\
\text { sentence : } \\
\text { Her mother was very } \\
\text { sad and cursed to stone. }\end{array}$ & $\begin{array}{l}\text { It should be : } \\
\text { Her mother was very sad and } \\
\text { cursed her into a stone. }\end{array}$ \\
\hline \multirow{2}{*}{3.} & \multirow{2}{*}{$\mathbf{X} 7$} & $\begin{array}{l}\mathrm{X} 7 \text { had difficulties in } \\
\text { writing past tense. } \\
\mathrm{He} / \text { she wrotem: } \\
\text { pick up } \\
\text { wake up }\end{array}$ & $\begin{array}{l}\text { The words should be : } \\
\text { picked up } \\
\text { woke up }\end{array}$ \\
\hline & & $\begin{array}{l}\text { Then, he/she also had } \\
\text { difficulties in pronouns. } \\
\text { He/she wrote : } \\
\text { He pick up the and } \\
\text { winded it the tiger. }\end{array}$ & $\begin{array}{l}\text { It should be : } \\
\text { He picked the snake up and } \\
\text { winded him to the tiger. }\end{array}$ \\
\hline 4. & X9 & $\begin{array}{l}\text { X7 had difficulties in } \\
\text { writing past tense. } \\
\text { He/she wrote : } \\
\text { is, feels, turns and dies. }\end{array}$ & $\begin{array}{l}\text { The words should be : } \\
\text { was, felt, turned and dead. }\end{array}$ \\
\hline
\end{tabular}




\begin{tabular}{|c|c|c|c|}
\hline \multirow{3}{*}{5.} & \multirow{3}{*}{ X11 } & $\begin{array}{l}\text { X11 had difficulties in } \\
\text { writing nouns and verbs. } \\
\text { He/she wrote: } \\
\text { mouse beer } \\
\text { sanake }\end{array}$ & $\begin{array}{l}\text { The nouns should be : } \\
\text { the mouse deer } \\
\text { the snake }\end{array}$ \\
\hline & & $\begin{array}{l}\text { Then, he/she wrote } \\
\text { rin, wander, lell, and } \\
\text { sleping. }\end{array}$ & $\begin{array}{l}\text { The verbs should be : } \\
\text { ran, wanted, fell and sleeping. }\end{array}$ \\
\hline & & $\begin{array}{l}\text { He/she also wrote } \\
\text { modifiers "a big } \\
\text { black..." without a noun. }\end{array}$ & $\begin{array}{l}\text { It should be : } \\
\text { A big black snake }\end{array}$ \\
\hline \multirow[b]{3}{*}{6.} & \multirow[b]{3}{*}{$\mathrm{X} 12$} & $\begin{array}{l}\text { X12 had difficulties in } \\
\text { writing past tense. } \\
\text { He/she wrote : } \\
\text { is, feels, turns and dies. }\end{array}$ & $\begin{array}{l}\text { The words should be : } \\
\text { was, felt, turned and dead. }\end{array}$ \\
\hline & & $\begin{array}{l}\text { He/she also had } \\
\text { difficulties in writing } \\
\text { direct speech and verbal } \\
\text { process. He/she did not } \\
\text { use quotation marks (“" “) }\end{array}$ & $\begin{array}{l}\text { "The king of the forest give } \\
\text { you a tribute" he said. }\end{array}$ \\
\hline & & $\begin{array}{l}\text { for direct speech in some } \\
\text { of sentences. He/she also } \\
\text { did not write verbal } \\
\text { processes/saying words } \\
\text { before or after quotation } \\
\text { marks (“" “). }\end{array}$ & "Hurry up" he said. \\
\hline
\end{tabular}

The king of the forest

gave you a tribute

Hurry up 


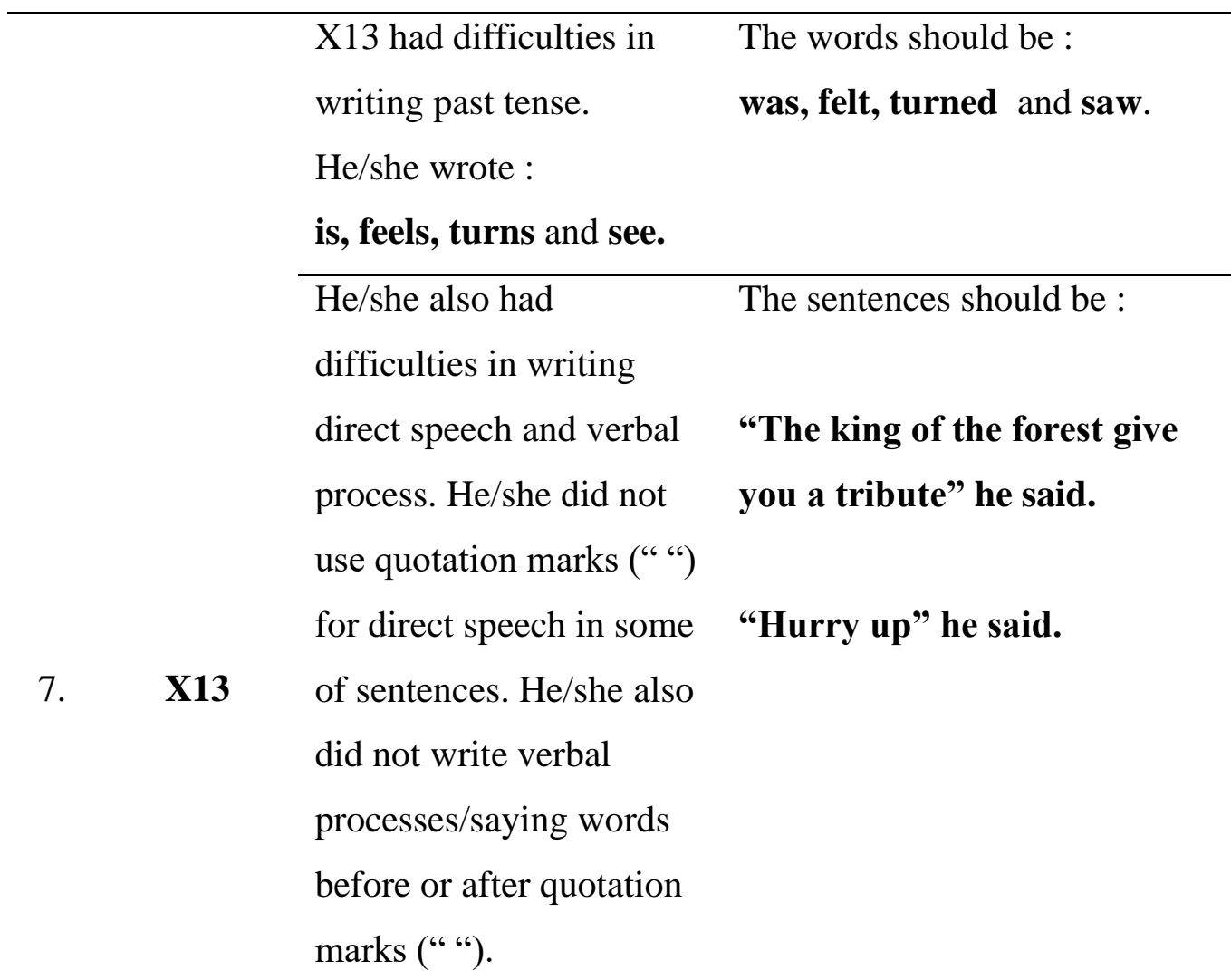

The king of the forest

give you a tribute

Hurry up

\begin{tabular}{|c|c|c|c|}
\hline 8. & X14 & $\begin{array}{l}\text { X14 had difficulties in } \\
\text { writing nouns, material } \\
\text { processes, and verbal } \\
\text { processes. He/she wrote : } \\
\text { the thre }\end{array}$ & $\begin{array}{l}\text { It should be : } \\
\text { the tree }\end{array}$ \\
\hline & & $\begin{array}{l}\text { Then, he/she wrote: } \\
\text { Beeged }\end{array}$ & $\begin{array}{l}\text { It should be : } \\
\text { begged }\end{array}$ \\
\hline
\end{tabular}




\begin{tabular}{|c|c|c|c|}
\hline & & $\begin{array}{l}\text { He/she did not write only } \\
\text { once but the words were } \\
\text { written several times. }\end{array}$ & \\
\hline \multirow[b]{2}{*}{9.} & \multirow[b]{2}{*}{ X18 } & $\begin{array}{l}\text { X18 had difficulties in } \\
\text { writing nouns and } \\
\text { conjunctions. } \\
\text { He/she wrote: } \\
\text { the deer } \\
\text { the der }\end{array}$ & $\begin{array}{l}\text { It should be : } \\
\text { the mouse deer }\end{array}$ \\
\hline & & $\begin{array}{l}\text { He/she also wrote "that" } \\
\text { as conjuction in several } \\
\text { sentences. } \\
\text { The deer looked for } \\
\text { various ways that the } \\
\text { tiger could realease it. }\end{array}$ & $\begin{array}{l}\text { It should be "then" or "so". } \\
\text { The mouse deer looked for } \\
\text { various ways so the tiger } \\
\text { could realease him. }\end{array}$ \\
\hline \multirow[t]{3}{*}{10.} & \multirow[t]{3}{*}{ X19 } & $\begin{array}{l}\text { X18 had difficulties in } \\
\text { writing pronouns, } \\
\text { conjunctions, and to be } \\
\text { (past tense). He/she } \\
\text { wrote "her brothers". } \\
\text { One day, two step sister } \\
\text { received to the ball. } \\
\text { Cinderela felt sad when } \\
\text { her brother's brother } \\
\text { left. }\end{array}$ & $\begin{array}{l}\text { One day, Cinderella's two } \\
\text { step sisters received to the } \\
\text { ball. } \\
\text { Cinderela felt sad when her } \\
\text { sisters left. }\end{array}$ \\
\hline & & $\begin{array}{l}\text { And then, he/she wrote } \\
\text { "he" }\end{array}$ & $\begin{array}{l}\text { It should be "she" because } \\
\text { Cinderella is a girl. }\end{array}$ \\
\hline & & He met the prince. & She met the prince. \\
\hline
\end{tabular}




\section{$\mathrm{He} / \mathrm{she}$ also wrote : $\quad$ The setence should be : \\ Finally Cinderella or Finally, Cinderella and \\ Prince alive \\ Prince were alive.}

The data displayed that the errors made by the students were connected to grammar, vocabulary and language use in writing skills. In this research, most students had difficulties in using past tenses. They did not pay attention to changing of verb in past tense and past continuous. The errors in the verb changing were so dilemmatic. Actually, the students were taught to use the past form of the verb when they wrote the past tense, but the errors still happened so frequently. The inferring factor could be the structure of the students' mother tongue since they did not have any verb changing in stating the past events (Fadilah, 2019). The absence of such structure would impact the students' understanding of past tense.

\section{CONCLUSIONS AND SUGGESTIONS}

There were 8 students (40\%) of 20 students had difficulties in constructing the generic structure of narrative texts. The researcher found 4 types of students' difficulties in the generic structure of writing narrative text. Firstly, some of students only wrote orientation and complication without resolution that contained ending of the story. Secondly, some of students only wrote complications and resolutions without orientation that told the main character of the story. Thirdly, some of students only wrote orientation, they did not write complication and resolution. Fourth, some of students only wrote orientation without complication and resolution. Furthermore, there were 10 students (50\%) of 20 students who had difficulties in using language features of narrative texts. It seemed that most of students had difficulties in using past tenses, especially the problems in verb changing. In writing the past tenses, it was hard for the students to differentiate between verb in the present form (verb 1) and verb in the past form (verb 2). Most of the students used present tense in their narrative texts.

This research was concluded to find the difficulties in writing narrative text faced by the ninth grade students of SMP Negeri 11 Palangka Raya. Based on the 
conclusion data above, the students had difficulties in generic structure and language features in writing narrative text. However, language features had more difficulties than generic structure, especially in using the past tense. It was not easy for the students to follow all the rules of past tense due to the absence of the same structure in their mother tongue.

\section{REFERENCES}

Bracaj, M. M. (2014). Teaching English for specific purposes and teacher training. European Scientific Journal, 10(2), 40-49.

Cresswell, J. W. 2012. Educational research: planning, conducting, and evaluating quantitative and qualitative research. Boston: Pearson Education.

Fadilah. (2019). An analysis of error on the use of simple past tense in writing narrative text of 42 State SMK in Jakarta. Wanastra, 11(1), 15-24.

Fareed, M., Ashraf, A., \& Bilal, M. 2016. ESL learners writing skills: Problems, factors, and suggestions. Journal of Education and Social Sciences, 4(2), $81-92$.

Fry, R. 2012. How to Study. USA: Course Technology PTR.

https://studylib.net/doc/18664215/beyond-the-4-skills--looking-at-21stcentury-skills

Javid, C.Z. (2015). English for specific purposes: Role of learners, teachers and teaching methodologies. European Scientific Journal, 11(20), 17-34.

Klimova, B.F. (2014). Pedagogical approaches and principles to the teaching of english for academic purposes. Discourse and Interaction, 7(1), 19-32. doi: 10.5817/DI2014-1-19

Lieberman, A. \& Miller, L. 2011. Learning communities. Learning Forwards, 32(4): 4-17.

Longknife, A. \& Sullivan, K. D. 2012. Essay writing skill step-by-step. New York: McGraw-Hill.

Morse, S. 2016. Beyond the 4 skills: Looking at $21^{\text {st }}$ century skills. Retrieved from

Nuzhatun, L. 2016. An analysis of students' problems in writing narrative text: a case study at second grade students of SMKN 1 Praya Tengah in academic year 2015/2016. Unpublished Thesis. Medan: Universitas Mataram.

Oshima, A. and Hogue, A. 1998. Writing Academic English, Thrid Edition. New York: Addition Wesley Longman.

Sharma, B.K. (2008). World englishes, English as a lingua franca, and English pedagogy. Journal of NELTA, 13(1), 121-130.

Septha Muliani

LET: Linguistics, Literature and Language Teaching Journal Vol. 9 No. 22019 
Simons, G. F. \& Fennig, C. D. 2018. Ethnologue: Languages of the world, twentyfirst edition. Texas: SIL International.

Sudarwati, T. M. \& Grace, E. 2017. Pathway to English 2. Jakarta: Erlangga.

Susanti, P. M. 2017. An error analysis on the use of past tense in narrative text. Unpublished Thesis. Medan: Universitas Negeri Medan

Ur, P. (2010). English as a lingua franca: A teacher's perspective. Cadernos de Letras (URFJ) 27, 85-91. http://www.letras.ufrj.br/anglo_germanicas/ cadernos/numeros/122010/textos/c1301220100penny.pdf. 